\title{
51. CONTROLS ON THE PLIOCENE-PLEISTOCENE EVOLUTION OF THE NORTHEASTERN AUSTRALIAN CONTINENTAL MARGIN ${ }^{1}$
}

\author{
Peter J. Davies² and Judith A. McKenzie ${ }^{3}$
}

\begin{abstract}
The continental margin of northeastern Australia is an excellent analogue for pure carbonate and mixed carbonate/siliciclastic association, a scenario that has occurred repeatedly throughout geological time. Here, we review the results of Ocean Drilling Program (ODP) drilling along the margin of the Great Barrier Reef aimed at (1) defining an event history for the margin and in particular analyzing the relationship between sedimentation and sea-level history, and (2) understanding the origin of the Great Barrier Reef.

When comparing results from the basin (Site 823), the lower slope (Site 822), and the upper slope (Site 820), many events can be recognized at all three sites. The most detailed event history, however, is present in the upper slope Site 820 .

The process response relationship in the basin is clear. Turbidites characterize both high and low sea levels; debris flows characterize the lowstands, whereas slump deposits define periods of major slope instability during lowstands and occasionally during transgressions.

The relationship between events and seismic character is not always clear. On the lower slope at Site 822, every sequence boundary identified in the site survey data correlates with a principal low sea-level event. However, at Site 820 on the upper slope, this is not the case; for example, the boundary between sequences $4 / 5$ at a depth of approximately $150 \mathrm{mbsf}$ appears to correspond with a highstand. At this site, the high-resolution isotope signal (= sea level) indicates that many more major sea-level excursions have occurred than are actually seen on the seismic record. In fact, most seismic reflectors are sequence boundaries. At this site, too, a detailed sediment response to a sea-level oscillation is defined.

Data from Site 820 define the age of the Great Barrier Reef as less than 500,000 yr. Data from Sites $811 / 825$ and 820 define the initiation of the Great Barrier Reef as related to a change in the frequency of climate change and an increase in surface-water temperatures over northeastern Australia at this time. The Queensland Plateau is nominated as the source for the coral planulae that rapidly colonized the Queensland continental margin. Since 500,000 yr ago, the Great Barrier Reef has been destroyed on numerous occasions by oscillating sea level.
\end{abstract}

\section{INTRODUCTION}

The $9300-\mathrm{km}^{2}$ continental margin of northeast Australian defines the largest area of mixed siliciclastic/carbonate deposition on Earth. Its tectonic setting on a young passive margin proximal to major depocenters makes it of immense scientific interest as an analogue for similar associations that have occurred repeatedly during geologic time. Further, the occurrence of the Great Barrier Reef along the continental shelf enormously increases both interest in and expectations from the research in the area. The pre-cruise objectives of ODP Leg 133 were as follows:

1. To define the sedimentary response to global sea-level changes in the late Cenozoic and Quaternary.

2. To define the influences of paleochemistry, paleoclimate, and paleoceanography on the initiation, growth, and demise of carbonate platforms and, specifically, the Great Barrier Reef.

3. To define slope-to-basin differences in sediment response and to understand the diagenetic processes operating in such areas.

A critical examination of the results from Leg 133 will be made by more than the usual marine geoscientists who regularly read and are interested in ODP literature. In the austral spring of 1990, biologists and concerned environmentalists watched as a neopetroleum drilling operation was conducted in the Great Barrier Reef Marine Park - an operation that was originally anathema to all environmental groups. However, the drilling clearly held promise of exciting discov-

${ }^{1}$ McKenzie, J.A., Davies, P.J., Palmer-Julson, A., et al., 1993. Proc. ODP, Sci. Results, 133: College Station, TX (Ocean Drilling Program).

${ }^{2}$ University of Sydney, Sydney, Australia 2006.

${ }^{3}$ ETH-Zentrum, CH-8092, Zurich, Switzerland. eries, not the least of which were clues to the origin of the Great Barrier Reef itself. Official permission, therefore, had been forthcoming and for that we wish to register our thanks to the executives of the Great Barrier Reef Marine Park Authority for their foresight. As events unfolded during that 1990 southern spring, ODP technical expertise proved clearly that it was possible to drill safely to moderate depths in Great Barrier Reef waters; Armageddon did not occur through a petroleum discovery, a blow-out, or some other environmental disaster. The operation was safe and environmentally clean and, importantly, the core recovery in the drill holes in the slope of the Great Barrier Reef was nearly $100 \%$, making it scientifically both highly rewarding and exciting, as well as an outstanding operational success. The co-chief scientists were thankfully absolved of being forever known as "they that destroyed the Great Barrier Reef." However, a small scientific hitch did occur during the drillingpaleontological dating at termination depth in the holes in the slope of the Great Barrier Reef indicated maximum ages of 1.4 (Sites 819, 820 , and 821 ) and 2.4 (Site 822) Ma, not the expected early Pliocene age. This was a surprise; the slope of the Great Barrier Reef clearly is an area of much more rapid deposition than had been previously thought. However, it also defined an incredible bonus - the highest resolution middle to late Pleistocene section ever obtained.

For this preliminary synthesis of the Leg 133 drilling results on the margin of the Great Barrier Reef, we define the following objectives:

1. To distill an event history for the margin and to examine particularly the sedimentary response to sea-level change.

2 . To confront the relevance of the drilling results to an understanding of the evolution of the Great Barrier Reef.

For the purpose of this review, the margin of the Great Barrier Reef is taken as the shelf-to-basin transect that includes Sites 821, 820, 819, 822 , and 823 ; however, when defining the relative importance of 
various processes, we also examined the concomitant record on the Queensland Plateau (Sites 811, 824, and 825) to understand whether such processes are of local or regional significance.

\section{EVENT STRATIGRAPHY OF THE NORTHEASTERN AUSTRALIAN MARGIN}

Drilling at Sites 819 through 823 penetrated to different depths (Davies, McKenzie, Palmer-Julson, et al., 1991); basinal sites penetrated much deeper and were generally older at a much shallower depth than the upper margin sites. The basinal sites thus define a lower resolution, but longer duration, history than do the upper slopes sites. It is basinal Site 823 , therefore, that we first examine to define a relatively low-resolution Pliocene/Pleistocene event history for the margin of the Great Barrier Reef. A correlation of the events on the upper slope, lower slope, and basin are shown in Table 1 and are described herein.

\section{Site 823-Basin}

Using many of the petrologic, sedimentological, and depositional conclusions in Watts et al. (this volume), the calcium carbonate data defined in Davies, McKenzie, Palmer-Julson, et al. (1991), and the clear association between carbonate, isotopes, susceptibility, grain size, and sea level defined in Peerdeman and Davies (this volume), we identified 15 major events in the top $330 \mathrm{~m}$ of Site 823. Beginning at the base of lithologic Subunit IIB, defined by Watts et al. (this volume) at a depth of approximately $340 \mathrm{mbsf}$, we identified the following gross event stratigraphy:

\section{Event 1}

Prior to $2.6 \mathrm{Ma}$, sea level was high and the shelf was drowned. Basin sediments are characterized by abundant high-sea-level turbidites showing both fining- and coarsening-upward sequences. Little terrestrial influence is seen in the way of quartz or bioclasts. Carbonate values are high and related to pelagic sedimentation. Major slope instability characterizes the end of this event, as seen in the development of a 12-m slump section. This event or complex of events characterizes Subunit IIB of Watts et al. (this volume).

\section{Event 2}

Between 2.6 and 2.4 Ma, the exposure of the Queensland continental margin is seen by a marked decrease in $\mathrm{CaCO}_{3}$ and substantial influxes of quartz, bioclasts, and continued slumping and the further development of turbidites. In the quartz data, this is seen as two distinct peaks and thus may relate to two distinct sea-level falls at 2.6 and $2.4 \mathrm{Ma}$.

\section{Event 3}

High sea level is shown by high carbonate and low quartz. However, on the basis of a comparison with values lower in the core, sea level may not have been high. Turbidites are common in this interval, corresponding to a time when only the outer shelf probably was flooded.

\section{Event 4}

Exposure of shelf and upper slope at about 1.8 Ma is indicated by two major perturbations in the quartz and bioclasts and a small decrease in the carbonate content. Turbidites characterize this part of the section.

\section{Event 5}

Between 1.8 and 1.6 Ma, a period of general lowstand is indicated by a substantial decrease in carbonate content and by fluctuations in quartz and bioclasts. Debris flows and slumped intervals characterize this part of the section.

\section{Event 6}

At about $1.6 \mathrm{Ma}$, a highstand is indicated by substantial declines in quartz content and bioclasts and an increase in carbonate content. It appears that debris flows characterize this high sea-level event.

\section{Event 7}

Between 1.6 and 1.3 Ma, a period of fluctuating sea levels is indicated by increases in quartz, bioclasts, and foraminifers. Carbonate fluctuates substantially, culminating in a major decrease at about 1.3 Ma. The section is dominated by debris flows, slumped deposits, and turbidites. Only turbidites appear to have accompanied the proposed major sea-level fall at 1.3 Ma.

Events 2 through 7 occur within and characterize Subunit IIA of Watts et al. (this volume).

\section{Event 8}

A highstand, slightly younger than $1.3 \mathrm{Ma}$, is indicated by low quartz/bioclasts and high carbonate content. Turbidites characterize this highstand part of the section.

\section{Event 9}

Between approximately 1.25 and $1.0 \mathrm{Ma}$, a period of fluctuating, but generally falling, sea level is indicated by substantial oscillations of carbonate and generally increasing quartz and bioclasts. Debris deposits appear to accompany these lowstands, whereas slump deposits accompany the regressions.

\section{Event 10}

Between 1.0 and $0.6 \mathrm{Ma}$, a rise in sea level is indicated by a substantial increase in carbonate content of the sediments. The section is also characterized by substantial slope instability, as indicated by a +20 -m section of slumps.

\section{Event 11}

Between 0.5 and $0.6 \mathrm{Ma}$, major debris deposits, high quartz/bioclasts abundances, and low carbonate content indicate low sea level, which may correlate with isotope stage 16 (through analogy with the data of Peerdeman et al., this volume).

\section{Event 12}

A period of extensive turbidite deposition corresponds with isotope stages 10 through 12 and, thus, the period of the change in frequency of isotopes (= sea level) at Site 820 (Peerdeman et al, this volume). This represents both a marked shift and fluctuation in isotopic composition (sea level).

\section{Event 13}

This period of major debris flows immediately preceding a decrease in carbonate content has been dated at younger than 280 k.y. and is probably associated with the falls in sea level that correspond to isotope stages 6 and 8 .

\section{Event 14}

A rise in carbonate content that corresponds with an age of about 120 k.y. suggests high sea levels, characterized by hemiplegic sedimentation and the absence of turbidites. 
Table 1. Event history for margin of the Great Barrier Reef for the past 2.6 Ma.

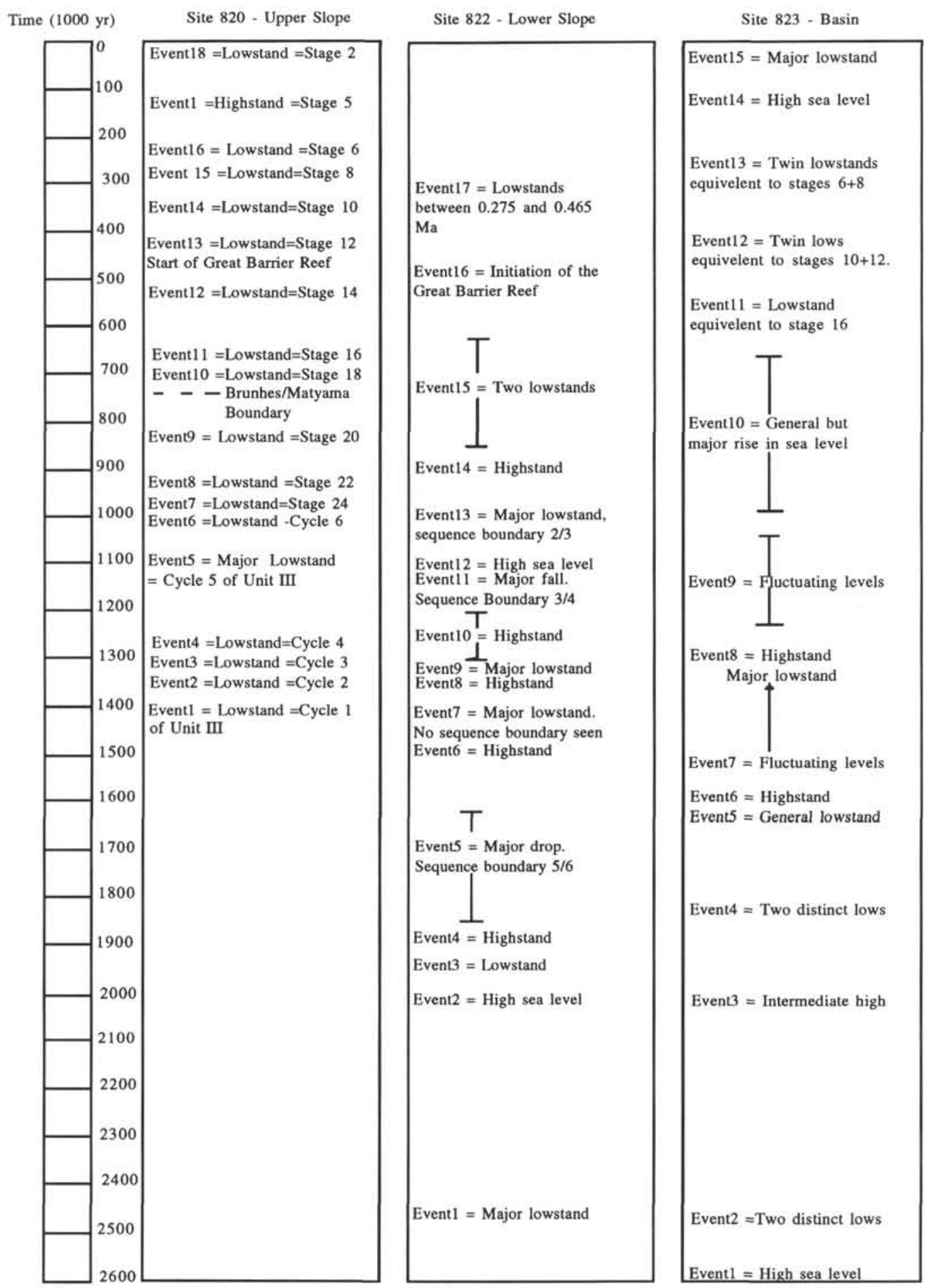

\section{Event 15}

Debris flows associated with a major decrease in carbonate content have been interpreted as representing deposition in the $18 \mathrm{k} . \mathrm{y}$. low.

\section{Site 822-Lower Slope}

Interpretations of the seismic, well-log, core, and geochemical data are used in conjunction with deep-sea isotope data to reconstruct the event history for Site 822 on the lower slope fronting the Great Barrier Reef. As can be seen, every sequence boundary corresponds with a substantial shift in carbonate content that can be matched with the deep-sea isotope curve within the confines of the dating.

\section{Event 1}

An increase in the quartz content of the sediments, together with a dramatic oscillation in the carbonate content at a depth of about 400 
mbsf in the drill hole, coincides with an interpreted sequence boundary between sequences 6 and 7 in lithologic Subunit IIC and has been dated at between 2.29 and $2.6 \mathrm{Ma}$. We think that this represents a substantial fall in sea level and may correspond to any or all of the major falls at 2.31, 2.4, and 2.48 Ma. This roughly correlates with event 2 in Site 823 , as described by Watts et al. (this volume), as defining the rejuvenation of the Queensland continental margin.

\section{Event 2}

The sediments indicate a sharp decrease in quartz and an abrupt increase in carbonate. We think that this represents a high-sea-level event at about $2.0 \mathrm{Ma}$ and that may correspond with event 3 at Site 823 .

\section{Event 3}

A lowstand event or events at 1.9 to $1.95 \mathrm{Ma}$ is indicated by the similarity in the shape of the double carbonate peak and a similar variation in the deep-sea isotope curve. However, note that these events are not seen as sequence boundaries in the seismic record, nor were they recognized on the lithologies described aboard the ship. Therefore, the recognition of this event relies entirely on the variations in carbonate content.

\section{Event 4}

A high sea-level event is recognized on the carbonate variation curve and lies close to the dated horizon of $1.88 \mathrm{Ma}$.

\section{Event 5}

The boundary between sequences 5 and 6 corresponds to a substantial decrease in the carbonate content and a substantial influx of quartz. This occurs between the two defined nannofossil datums of 1.48 and $1.88 \mathrm{Ma}$ and most reasonably represents one or all of the falls (shown on the deep-sea isotope curve to occur) at $1.62,1.67,1.7$, or $1.78 \mathrm{Ma}$. We think that this event most likely represents the falls between 1.6 and 1.7 Ma because they appear to be the most prolonged and thus most likely to have given rise to a recognizable sequence boundary.

\section{Event 6}

An increase in carbonate content reaches a distinct maximum immediately prior to the horizon dated at $1.48 \mathrm{Ma}$. We suggest, therefore, that event 6 represents the highstand shown on the deep-sea isotope curve as occurring at this time.

\section{Event 7}

We define this from the substantial reduction in carbonate estimated to have occurred at $1.45 \mathrm{Ma}$ and thus corresponding to the sea-level fall shown on the deep-sea isotope curve. No corresponding sequence boundary was recognized at this location.

\section{Event 8}

The high carbonate content clearly recognized in the lithology at 270 mbsf (and that separates distinctly clay units above and below) also is seen as a peak in the carbonate curve. We suggest that this represents the high sea level seen in the deep-sea curve at 1.35 Ma.

\section{Event 9}

The reduction in carbonate, the corresponding development of a dominantly clay-rich sequence, and the recognition of a sequence boundary between sequences 4 and 5 at this depth define a low-sealevel event of some magnitude. We propose that this represents the substantial fall at about $1.33 \mathrm{Ma}$, seen on the deep-sea isotope curve.

\section{Event 10}

We propose that the distinct increase in carbonate content at a depth of $210 \mathrm{mbsf}$ defines one of the high sea levels between 1.21 and $1.33 \mathrm{Ma}$.

\section{Event 11}

The sequence boundary separating sequences 3 and 4 and the corresponding decrease in carbonate content and increase in clay content have been interpreted as being related to the substantial fall in sea level identified as occurring at about 1.13 Ma.

\section{Event 12}

A dramatic and substantial increase in carbonate content defines the basal part of Subunit IIA. We postulate that this defines one or both of the high-sea-level events that occurred at about 1.1 or $1.2 \mathrm{Ma}$.

\section{Event 13}

The sequence boundary between sequences 2 and 3 , the marked decrease in carbonate content, and the thick clay sequence define a low-sea-level event, identified as the one occurring at 1.09 Ma on the deep-sea isotope curve. The sequence boundary defines a fundamental change in the sedimentology of the margin, with a distinct increase in carbonate content occurring in the period 0.9 to $1.09 \mathrm{Ma}$.

\section{Event 14}

The section between 80 and 105 mbsf contains more carbonate than any part of the section below. We think that this defines a period of sustained high sea level between 0.95 and $0.87 \mathrm{Ma}$.

\section{Event 15}

The carbonate curve shows two sharp oscillations between 60 and 80 mbsf. We identified these as probably representing the fall corresponding with 0.63 and $0.87 \mathrm{Ma}$. The youngest oscillation coincides with the sequence boundary between sequences 1 and 2 and lithologic Units I and II. This almost certainly represents substantial erosion.

\section{Event 16}

Upward from a depth of $60 \mathrm{mbsf}$, a substantial change takes place in the sediments reaching Site 822 (i.e., a large increase can be seen in the amount of carbonate deposited over anything deposited earlier in the section). We postulate that this corresponds with a rise in sea level between 0.5 and $0.6 \mathrm{Ma}$ and that this indicates a fundamental change in carbonate production on the shelf (i.e., the turning on of the Great Barrier Reef as a tropical reef system). This corresponds with events 10 through 12 at Site 823 .

\section{Event 17}

The hiatus defined in the biostratigraphy corresponds with a decrease in carbonate and may represent any of the lows between 0.275 and $0.465 \mathrm{Ma}$.

\section{Site 820-Upper Slope}

Detailed sedimentological studies at Site 820 (Feary, this volume, and Feary and Jarrard, this volume) define three major units: an upper aggradational (Unit I), a middle transitional (Unit II), and a lower progradational (Unit III). Within these units, Feary (this volume) recognized a number of sedimentological sequences, the boundaries of many of which correspond to sequences boundaries recognized in the seismic data (Feary et al., this volume). We agree that the section 
at Site 820 can be divided into three sections, but on the basis of the isotope (Peerdeman et al., this volume), susceptibility (Barton et al. this volume), and lithology, carbonate, and grain size (Feary and Jarrard, this volume) data, we think that the section may be better subdivided as follows:

1. An upper division between 0 and $70 \mathrm{mbsf}$, encompassing isotope stages 1 through 8 and, therefore, extending in age from 0 to $400,000 \mathrm{yr}$ B.P. This equates with seismic sequences 1 and 2 and the upper half of Unit I of Feary and Jarrard (this volume). In this section, the isotopes, mineralogic variations, and susceptibility variations correlate and appear to exhibit a low-frequency signal.

2. A middle division between 70 and 150 mbsf equivalent to seismic sequences 3 and 4 , and isotope stages 8 through to 20 , that extends in age from 400,000 to $730,000 \mathrm{yr}$ B.P. This is characterized by high-frequency oscillations in isotopes, mineralogy, and susceptibility. The base of the division is the Brunhes/Matuyama boundary: divisions 1 and 2 define an essentially aggrading part of the stratigraphic section that corresponds with Unit I of Feary and Jarrard (this volume).

3. A lower division between 150 and 400 mbsf equivalent to seismic sequences 5 to 9, and lithologic Units II and III of Feary and Jarrard (this volume), that extends in age from $730,000 \mathrm{yr}$ to less than 1.4 Ma. The division is characterized by relatively low-frequency oscillations in susceptibility (Barton et al., this volume), and mineralogy (Feary and Jarrard, this volume) and the development of thick cyclical lithologic units as a consequence of a high sedimentation rate. This lower division is characterized by progradation.

When defining an event stratigraphy for Site 820 , we used the broad divisions outlined herein for defining groups of events that we think clearly link sedimentation and causal processes. In Table 1, we define 18 major sea-level lows that are the principal events defined for Site 820 . Above a depth of $200 \mathrm{mbsf}$, these can be correlated with isotope stages (Peerdeman et al., this volume). Below a depth of 200 mbsf, our lack of high-resolution age control makes this much more difficult, and we thus have not attempted a cross-correlation with isotope stages. In the lower division, however, we recognize nine events that correlate with the cycles in Units II and III of Feary and Jarrard (this volume); events 7,8, and 9 correlate with isotope stages 24,22 , and 20 , respectively. In the middle division, we recognized at least six events (10-15) corresponding to isotope stages 8-18. In the upper division, we define three principal events that correspond to isotope stages 2,5 , and 6 .

Comparing the events defined in Table 1 for the upper and lower slope and the basin, two points are clear: (1) many events are seen in all three environments and (2) many more events are recognized on the upper slope than in the lower slope and basin sections. Neither of these conclusions is surprising.

A substantial part of the Leg 133 program was aimed at defining the sedimentary response to global climate change and as such it represented the first attempt by ODP to confront directly and to test global sequence stratigraphic concepts. From the beginning, we thought that the best place for testing such ideas was along continental margins, particularly along mixed carbonate/siliciclastic margins, because of the greater opportunity for high-resolution sections.

Along the margin of the Great Barrier Reef, the process/response relationships are discernible at all sites. In the basin at Site 823, detailed relationships are not always clear, but some important conclusions can be drawn: (1) turbidites characterize both high and low sea-level periods; (2) debris flows characterize the lowstands, and (3) slump deposits define periods of major slope instability in the lows and sometimes during the transgressions.

At Site 822 , every single sequence boundary can be correlated with a principal low sea-level event. The same cannot be said of Site 820 , where the boundary between sequences 4 and 5 at a depth of approximately $150 \mathrm{~m}$ appears to correspond with a high sea-level event. In addition, the high-resolution isotope signal indicates that many more sequence boundaries really are related to shifts in sea level than in fact can be recognized in the seismic data, which are far higher in quality and resolution than those used in most studies. In fact, each seismic reflector is a sequence boundary.

The upper slope Site 820 provides the most detailed signals of process/response relationships on a continental margin. This site is particularly useful because of the independent control of the sealevel/climate history defĩned by the isotopic studies and interpretations (Peerdeman et al. and Peerdeman and Davies, this volume); i.e., the sedimentological response can be fitted to an independently defined sea-level history, unlike most studies where sea-level history is deduced from the sedimentary character of the section. Further, the section is a high-resolution one by any standards and thus permits analysis of process and response at different times during the sea-level oscillation.

Peerdeman and Davies (this volume) defined a detailed sedimentological response for the last sea-level oscillation that incorporates distinct changes in the fall, the lowstand, the early transgression, the late transgression, and the highstand. They and Feary et al. (this volume) further extend this to an interpretation for the whole of the upper part of the aggradational unit (i.e., the upper division defined herein). However, Feary et al. considered that this same process/ response relationship does not hold for their Unit III, that is, the lower part of the progradational unit. For this, they invoke a different sedimentological response to oscillating sea level during progradation, as opposed to aggradation. Using the original data in Feary et al. (this volume) and Peerdeman and Davies (this volume), a comparison of the sedimentological response to oscillation is shown in Table 2. Clearly, no substantial difference exists between Units I and III, only in the late transgression, where low $\mathrm{CaCO}_{3}$ characterizes the progradational sequences, is any appreciable difference in sedimentological character seen. The detailed sedimentological response to sea-level oscillations on a mixed carbonate/siliciclastic margin such as the Great Barrier Reef thus is summarized as follows:

1. During the regression: A thoroughly mixed carbonate rich-sediment is produced. Sand makes up $15 \%$ to $60 \%$; mud varies from $15 \%$ to $60 \%$, while carbonate is high $(60 \%-75 \%)$.

2. During the stillstand: Sand is high, mud is low, and $\mathrm{CaCO}_{3}$ is high $(40 \%-80 \%)$. This is a carbonate-rich sandstone.

3. During the early transgression: Sediments are dominated by mud and are high in carbonate.

4. During the late transgression: Aggradation is characterized by carbonate-rich muds, whereas progradation is characterized by carbonate-poor muds.

5. During the highstand: Carbonate-rich muds dominate the upper slope.

Clearly, a marked differentiation in sediment type and composition accompanies a sea-level oscillation.

\section{THE EVOLUTION OF THE GREAT BARRIER REEF}

We think that any study of the evolution of the Great Barrier Reef must consider the timing of its initiation, the reasons for its initiation, where it came from, and both its mode of growth and propagation. The scientific results from Leg 133 are used here to examine each of these important points in turn.

\section{Initiation}

Ideas regarding the age of the Great Barrier Reef have changed fundamentally over the past $20 \mathrm{yr}$. Early ideas based on oil company drilling in the northern and southern reef region suggested that the reef may be 15 to $20 \mathrm{Ma}$ old. During the early to mid-1980s, Davies and colleagues at the Australian Geological Survey Organisation proposed that the reef was much younger-probably less than $3.5 \mathrm{Ma}$ 
Table 2. Sedimentary character of the margin of the Great Barrier Reef as a response to sea-level oscillation.

\begin{tabular}{|c|c|c|c|}
\hline Sea-level state & Unit 1 - Aggradation & Unit 2-Progradation & $A=P$ \\
\hline Lowstand & $\begin{array}{l}\text { Sand - High } \\
\text { Mud - Low <45\% } \\
\text { CaCO3 - High, } 65-80 \%\end{array}$ & $\begin{array}{l}\text { Sand - High 20-30\% } \\
\text { Mud - Low } \\
\mathrm{CaCO} \text { - High. } 60-40 \%\end{array}$ & $\begin{array}{l}\text { Very } \\
\text { Similar }\end{array}$ \\
\hline Early Transgression & $\begin{array}{l}\text { Sand - Low, } 10 \% \\
\text { Mud - High, }>90 \% \\
\mathrm{CaCO} \text { - Low }\end{array}$ & $\begin{array}{l}\text { Sand - } 20 \text { to } 2 \% \\
\text { Mud - High, }>80 \% \\
\text { CaCO3 - } 20 \text { to } 5 \% \text {. }\end{array}$ & $\begin{array}{l}\text { Very } \\
\text { Similar }\end{array}$ \\
\hline Late Transgression & $\begin{array}{l}\text { Sand - } 5 \text { to } 15 \% \\
\text { Mud }-80 \text { to } 95 \% \\
\mathrm{CaCO} 3-\text { Up to } 65 \%\end{array}$ & $\begin{array}{l}\text { Sand }-.2 \% \\
\text { Mud - High } \\
\mathrm{CaCO}-5 \text { to } 10 \%\end{array}$ & $\begin{array}{l}\mathrm{P}=\text { low } \\
\text { in Carb }\end{array}$ \\
\hline Highstand & $\begin{array}{l}\text { Sand - }<20 \% \\
\text { Mud - } 80 \text { to } 90 \% \\
\mathrm{CaCO} 3-65 \%\end{array}$ & $\begin{array}{l}\text { Sand - } 2-10 \% \\
\text { Mud - High } \\
\mathrm{CaCO}-5 \text { to } 60 \% \text {. }\end{array}$ & $\begin{array}{l}\mathrm{P}=\text { low } \\
\text { in Carb }\end{array}$ \\
\hline Regression & $\begin{array}{l}\text { Sand - } 15 \text { to } 60 \% \\
\text { Mud - } 85 \text { to } 40 \% \\
\text { CaCO3 }-75 \%\end{array}$ & $\begin{array}{l}\text { Sand }-30 \% \\
\text { Mud - } 70 \% \\
\mathrm{CaCO} 3-60 \%\end{array}$ & $\begin{array}{l}\text { Very } \\
\text { Similar }\end{array}$ \\
\hline Lowstand & $\begin{array}{l}\text { Sand - High } \\
\text { Mud - Low <45\% } \\
\mathrm{CaCO} 3 \text { - High, } 65-80 \%\end{array}$ & $\begin{array}{l}\text { Sand - High 20-30\% } \\
\text { Mud - Low } \\
\mathrm{CaCO} \text { - High, } 60-40 \%\end{array}$ & $\begin{array}{l}\text { Very } \\
\text { Similar }\end{array}$ \\
\hline
\end{tabular}

The last column $(\mathrm{A}=\mathrm{P})$ is a comparison of the character of the aggrading section with that of the prograding section.

old (Symonds et al., 1983; Davies et al., 1988). In the late 1980s, seismic data collected as part of the ODP drilling proposal were interpreted as showing certain seismic reflectors that could be traced westward under the Great Barrier Reef, and which Davies et al. (1989) considered to be early Pliocene. However, drilling at Sites 819 through 821 and paleontological dating of the reflectors indicated an age of between 500,000 and 900,000 yr (Davies et al., 1991), while the isotope work and pattern matching of stages with the deep-sea data (Peerdeman et al., this volume) suggest an age of $500,000 \mathrm{yr}$ or younger. This also corresponds with a fundamental increase in the carbonate content at Site 822 on the lower slope (Event 16 in Table 1), which thus might relate to an initiation mechanism for the Great Barrier Reef.

Note, however, that a partially contrary view has been postulated by Montaggioni et al. (this volume), who interpreted reef-related faunas, mainly benthic foraminifers, as having occurred throughout Site 820 . However, the faunas defined by Montaggioni et al. (this volume) are seen all over the outer shelf at the present time and are not specifically related to reefal areas. Therefore, we think that the overwhelming body of evidence indicates that the Great Barrier Reef may be less than $0.5 \mathrm{Ma}$ old. In terms of the three reef provinces of northeastern Australia, the Great Barrier Reef is the baby.

\section{Why Did the Great Barrier Reef Start When It Did?}

Studies by Isern et al. (this volume) on the Queensland Plateau defined variations in sea-surface temperature for the past $10 \mathrm{Ma}$. These data impinge fundamentally on any consideration of reef growth, because they indicate that the cause of reef growth must have been at least regional in extent. These data show a large increase in sea-surface water temperatures from less than $17^{\circ} \mathrm{C}$ (too cold for tropical reef development) to much greater than $18^{\circ} \mathrm{C}$ (conducive for reef development) between 0.6 and $0.8 \mathrm{Ma}$. Unfortunately, the resolution of the record is not sufficient to determine more precisely when this change occurred. The conclusion, however, is inescapable that sea-surface water temperatures on the Queensland Plateau were too cold for reef development before 600,000 to $800,0000 \mathrm{yr}$ ago.

Similar studies using cores from Site 820 (Peerdeman et al., this volume) define in far greater detail than is possible on the Queensland Plateau, the history of oxygen isotope variation in the Great Barrier Reef Province. At a depth of between 70 and $85 \mathrm{mbsf}$ at Site 820, the isotope record shows fundamental changes in frequency and amplitude that have been interpreted by Peerdeman et al. (this volume) as showing an increase in seawater temperature of about $3^{\circ}$ to $5^{\circ} \mathrm{C}$. On the basis of these interpretations, this is thought to have occurred at about $500,000 \mathrm{yr}$ or less, which is at the depth and age defined for the seismic reflectors that can be traced beneath the reef and thus define the timing of its initiation. This age also is near that determined by Isern et al. (this volume) for a similar temperature shift in the lowresolution section on the Queensland Plateau. Thus, we think that this co-occurrence of regional environmental change and reef initiation in the Great Barrier Reef Province is most unlikely to be coincidence. The initiation of the Great Barrier Reef must have been driven by a fundamental change in the controls of sea-surface water temperatures over northeastern Australia.

\section{Where Did the Great Barrier Reef Come From?}

Results from Leg 133 show that the reefs off northeastern Australia first are seen on the Marion and Queensland plateaus. Whereas the reefs of the Marion Plateau did not survive the mid-Miocene fall in sea level (Pigram et al., this volume), those of the Queensland Plateau did (McKenzie and Davies, this volume). We thus propose that the Queensland Plateau reefs form the cradle of the Great Barrier Reef. If this is the case, then it immediately brings into focus the importance of the regional oceanography as the predominant dispersal mechanism for transporting the necessary larvae to the Queensland margin for eventual initiation of the reef.

\section{How Did the Great Barrier Reef Evolve?}

In terms of its evolutionary development, we think that the essential environmental processes operating during the long and the short time frames need to be considered.

In the long time frame, drilling off northeastern Australia during Leg 133 confirmed that tropical reefs are underlain by temperate carbonate sediments comprising bryozoans, mollusks, and foraminifers (Davies, McKenzie, Palmer-Julson, et al., 1991; Brachert et al., this volume; McKenzie and Davies, this volume). The fundamental initiation of the reefs of northeastern Australia is related to the continental drift from the poles to the tropics. It defined and resulted in the following:

1. A total biological change from temperate to tropical faunas,

2. A change in the primary productivity of the oceans, and

3. A change in the regional oceanography.

This change occurred at about $15 \mathrm{Ma}$ before the present. A corollary is that as drift continues today, the reefs of the Great Barrier Reef will spread to the south as more of eastern Australia enters the tropics.

However, although plate tectonics and plate motions provided the initial impetus for the evolution of tropical faunas off northeastern Australia in the Queensland and Marion plateaus, other processes catalyzed the evolution of the Great Barrier Reef, and it is to these shorter-term processes that we must turn our attention to explain the evolution of the Great Barrier Reef after its initiation.

Evolution is partly about the interaction of a community with, and within, the available ecospace. An important question, therefore, is 
what produces new space and new interactions? In some ecosystems such as rain forests, major system perturbations such as destruction by fire are thought to effect the evolutionary development of the forest through wiping out part of the forest to produce new space for new interactions. Is this same concept applicable to coral reefs and the Great Barrier Reef in particular? Davies (1988) suggested that past changes in sea level may have acted as system perturbators. After all, reefs grow in the marine environment near sea level, and any change in the position of the sea level must perturb the growth dynamic of the reef. If sea level falls, the reef dies; if sea level rises, then the reef must change its faunal composition to accommodate the new water depth. Rises and falls of sea level thus are catalysts and destroyers of reefs.

The results from Leg 133 indicate that during the time of the growth of the Great Barrier Reef, the position of sea level varied substantially. Were the record of oxygen-isotope variation at Site 820 considered to be a qualitative proxy for sea-level change, then clearly fundamental alterations of sea level relative to present have occurred on numerous occasions in the past 800,000 yr. How have such changes affected the growth of reefs? Examining the proxy sea-level curve in Peerdeman and Davies (this volume), the shape of the sea-level alternations are asymmetric, with the rise more rapid than the fall. This is particularly so for isotope stages 1 through 5 over the last $125,000 \mathrm{yr}$. Although many small oscillations occurred, the trend from 125,000 to $18,000 \mathrm{yr}$ is of a general fall, perhaps more rapid prior to $70,000 \mathrm{yr}$ than after. When sea level falls rapidly, it is our hypothesis that a reef will be wiped out. If the fall in sea level is slow, one might expect that some species might migrate downward and colonize the lower slopes were space available; however, the essential processes would be that the old ecosystem would be abandoned and a new ecosystem constructed. Clearly, however, such a new ecosystem would be by definition an ephemeral transient feature, while sea level continued to fall. The main message, therefore, is that during this fall, only ephemeral ecosystems would develop. Their importance, however, is that they define potential nurseries for the next growth phases in the succeeding high sea level. In the Great Barrier Reef, low-sea-level reefs may have developed only along the steep upper continental slope or on the outer shelf of the central region to the east of Townsville. Thus, such regions represent the only areas that might have provided the coral planulae for the next major phase of reef growth concomitant with the succeeding rise in sea level. However, both areas define poor candidates as nurseries for two obvious reasons. First, the upper slope environment, inimical because of its steepness, its precarious open nature, and its existence as a site for the deposition of substantial low-sea-level muds, would have developed specialized faunas and probably not those that would have best colonized flat ground after the rise. Second, the outer shelf was itself exposed during the last phase of many of the falls and thus might not have acted as a nursery. To conclude, we postulate that a major fall in sea level will effectively destroy the reef ecosystem. On the basis of the isotope curve shown in Peerdeman et al. (this volume) and Peerdeman and Davies (this volume), we suggest that this has happened on numerous occasions since inception of the reef. Further, it is also clear that the source of the next reef must therefore be exogenous, that is, from outside the Great Barrier Reef.

It remains now to discuss the question, what happens during a rise in sea level coincident with a change from glacial to interglacial? The isotope curve in Peerdeman et al. (this volume) and especially in Peerdeman and Davies (this volume) indicates that these rises were substantially more rapid than the falls. The growth of a reef as a result of a rise is well known from many years of work in the Great Barrier Reef. Much more in fact is known about the growth of the reef than about the rise in sea level. However, let us examine both to define the interaction. A drilling program in the 1970 s and early 1980 s defined the thickness of the modern reef as varying from 8 to $28 \mathrm{~m}$ throughout the province and with few regional trends. Throughout the whole of the Great Barrier Reef, the reef started to grow between 8000 and
8500 yr ago (i.e., on the many reefs drilled, it started almost instantly and everywhere at the same time). The question is, why? Some scientists suggested that reef growth started when the rate of sea-level rise slowed down. However, were the isotope curve for a site in a water depth of nearly $300 \mathrm{~m}$ in any way related to change in sea level, the time period of 8000 to $9000 \mathrm{yr}$ is one when the rate of sea-level change either remained unaltered or sped up slightly (Peerdeman and Davies, this volume). Other scientists suggested that growth was triggered by a reduction in the phosphate content of sea water following the glacial rise (Kinsey and Davies, 1979). Whatever the reason, the same effect of instant reef initiation is seen throughout the Great Barrier Reef. Indeed, published and unpublished research shows that reef growth occurred at the same time in French Polynesia and southern Japan. With respect to sea-level change, therefore, the data indicate that reef initiation began late in the transgression.

\section{Implications}

From a geo-biological viewpoint, the conclusions outlined here have interesting and far-reaching consequences. Our conclusions raise questions about the importance of gradualism and catastrophism in reef evolution. A temperate ecosystem gave rise to a tropical ecosystem that was wiped out on many occasions. Although both gradualism and catastrophism theoretically may have played important parts, certainly during the development of the Great Barrier Reef catastrophe was significant. In the guise of sea-level oscillations, it both created new space and provided an opportunity for the development of substantial regional vicariance through the effects of physical barriers to dispersion and low-sea-level isolation. Like fire in the rain forest, sea-level oscillations may have provided the stimulus for substantial evolution.

In addition, and from an evolutionary viewpoint, the repeated recoveries testify to the robustness of the ecosystem. This is where ecologists feel most threatened by the geological assertions, so we should like to amplify this proposition. Systems of any sort can be perturbed, in both the short- and long-term. Biologists, considering only the short-term (10-20 yr), for example, define the Crown of Thorns starfish plague as a system perturbation and the reef ecosystem as fragile. The ecologist is correct. However, the geological experience is that as soon as the threat is removed and the environment returns to normal, then the reef ecosystem off northeastern Australia recovers, as long as an exogenous gene pool is available. The ecosystem is in toto robust. The geologist also is correct. Who is more correct is a function of whether one needs to use a microscope or a telescope. Philosophically, we should contend that biological "weather" is the noise in geological "climate."

Of far greater relevance to the reef manager, however, is the identification of the importance of an exogenous gene pool (a cradle) and the essential relevance of protecting and nurturing it. In the case of the Great Barrier Reef, we propose that this is the Queensland Plateau. Such an area assumes even greater importance during periods of global ecosystem shock or ecologic deterioration, as is purported to be occurring today (Brown, 1987; Salvat, 1987; Hodgson and Dixon 1988; Hatcher et al., 1989; Done, 1991). Far from downplaying this problem, we wish to highlight it further. Such dangerous situations can lead to extinction, where no amount of research and managing will help. The geologist, more than any other scientist, is familiar with the scenario. The most spectacular "recent" event occurred at the Cretaceous/Tertiary (K/T) boundary, about $65 \mathrm{Ma}$ ago, when fundamental global deterioration (some would say a nuclear winter induced by either extra-terrestrial collision or abnormally high terrestrial volcanism) caused fundamental extinction and a change of course in the evolution of the planet. The deterioration of today's reef, therefore, may be telling us fundamental truths about the health of the planet. Protection and study of those parts that are healthy thus are of paramount importance. As well as defining the life-blood of the future, such areas also provide a record of the reef ecosystem response 
to earlier changes that may impinge directly on the problems of the present. For example, the current global reef degradation is attributed to excess pollutant nitrate and phosphate in the world's oceans, whereas Kinsey and Davies (1979) claimed that high natural levels of such "nutrients" have inhibited and destroyed reefs many times in the past. Indeed Kinsey and Davies (1979) claimed that initiation of the modern reef system owes much to the reduction of oceanic phosphate and nitrate levels following the last glaciation. Although the current crisis may be anthropogenically induced, the mechanismresponse relationship has been identified in the past. It is fossilized in the reefs themselves through the ability of corals to record the chemical and physical attributes of the environment in which they live as well as their response to it. This record represents a priceless statement and one that we think must be understood.

\section{REFERENCES}

Brown, B.E., 1987. Worldwide death of corals: natural cyclic events or world wide pollution. Mar. Poll. Bull., 18:9-13.

Davies, P.J., 1988. Evolution of the Great Barrier Reef-Reductionist Dream or Expansionist Vision? Proc. 6th Int. Coral Reef Symp., 1:9-17.

Davies, P.J., Symonds, P.A., Feary, D.A., and Pigram, P.J., 1988. Horizontal plate motion: a key allocyclic factor in the evolution of the Great Barrier Reef. Science, 238:1697-1700.

, 1989. The evolution of the carbonate platforms of northeastern Australia. In Crevello, P.D., Wilson, J.L., Sarg, R., and Read, J.F. (Eds.),
Controls on Carbonate Platform and Basin Development. Soc. Econ. Paleontol. Mineral. Spec. Publ., 44:233-258.

Davies, P.J., McKenzie, J.A., and Palmer-Julson, A., 1991. Proc. ODP, Init. Repts., 133: College Station, TX (Ocean Drilling Program).

Done, T. 1991. The debate continues-robust versus fragile reefs. Reef Encounters, 9:5-7.

Hatcher, B.G., Johannes, R.E., and Robertson, A.I., 1989. Review of research relevant to the conservation of shallow-water tropical marine ecosystems. Mar. Biol. Ann. Rev., 27:337-414.

Hodgson, G., and Dixon, J.A., 1988. Logging versus fisheries and tourism in Palawan. Occ. Pap. East-West Environ. Pol. Inst., 7.

Kinsey, D.W., and Davies P.J., 1979. Effects of elevated nitrogen and phosphorus on coral reef growth. Limnol. Oceanogr., 24:935-940.

Salvat, B., 1987. Human impacts on coral reefs: facts and recommendations. Antenne Mus. Ecoile Prat. Hautes Etudes, French Polynesia.

Symonds, P.A., Davies, P.J., and Parisi, A., 1983. Structure and stratigraphy of the central Great Barrier Reef. BMR J. Austral. Geol. Geophys., $8: 277-291$.

\footnotetext{
* Abbreviations for names of organizations and publication titles in ODP reference lists follow the style given in Chemical Abstracts Service Source Index (published by American Chemical Society).
}

Date of initial receipt: 14 January 1993

Date of initial acceptance: 16 April 1993

Ms 133B-279 